\title{
Comparison of the efficacy of tenofovir and adefovir in the treatment of chronic hepatitis B: A Systematic Review
}

\author{
Shu-Shan Zhao ${ }^{1,2,3 \dagger}$, Lan-Hua Tang ${ }^{1,2,4+}{ }^{+}$Xia-Hong Dai ${ }^{1}$, Wei Wang ${ }^{5}$, Rong-Rong Zhou', Li-Zhang Chen ${ }^{6 *}$, \\ Xue-Gong Fan ${ }^{1 *}$
}

\begin{abstract}
Chronic viral hepatitis B remains a global public health concern. Currently, several drugs, such as tenofovir and adefovir, are recommended for treatment of patients with chronic hepatitis B. tenofovir is a nucleoside analog with selective activity against hepatitis $b$ virus and has been shown to be more potent in vitro than adefovir. But the results of trials comparing tenofovir and adefovir in the treatment of chronic hepatitis B were inconsistent. However, there was no systematic review on the comparison of the efficacy of tenofovir and adefovir in the treatment of chronic hepatitis B. To evaluate the comparison of the efficacy of tenofovir and adefovir in the treatment of chronic hepatitis B we conducted a systematic review and meta-analysis of clinical trials. We searched PUBMED, Web of Science, EMBASE, CNKI, VIP database, WANFANG database, the Cochrane Central Register of Controlled Trials and the Cochrane Database of Systematic Review. Finally six studies were left for analysis which involved 910 patients in total, of whom 576 were included in tenofovir groups and 334 were included in adefovir groups. At the end of 48-week treatment, tenofovir was superior to adefovir at the HBV-DNA suppression in patients $[\mathrm{RR}=2.59 ; 95 \% \mathrm{Cl}(1.01-6.67)$, $P=0.05]$. While there was no significant difference in the ALT normalization $[R R=1.15 ; 95 \% \mathrm{CI}(0.96-1.37), P=0.14]$, $\mathrm{HBeAg}$ seroconversion[RR $=1.32 ; 95 \% \mathrm{Cl}(1.00-1.75), \mathrm{P}=0.05]$ and $\mathrm{HBsAg}$ loss rate $[\mathrm{RR}=1.19 ; 95 \% \mathrm{Cl}(0.74-1.91)$, $P=0.48]$. More high-quality, well-designed, randomized controlled, multi-center trails are clearly needed to guide evolving standards of care for chronic hepatitis B.
\end{abstract}

\section{Introduction}

Chronic hepatitis B virus (HBV) infection is a serious global public health problem associated with cirrhosis, liver failure and hepatocellular carcinoma (HCC) [1]. Of the two billion people who have been infected, more than 350 million have chronic hepatitis [2]. Several major advances in the treatment of chronic hepatitis $B$ (CHB) have been made over the last several years. Currently, several drugs are recommended for treatment of patients with $\mathrm{CHB}$. These drugs can be divided into two main groups based on their mechanism of action, namely immunomodulatory drugs like alpha interferons

\footnotetext{
* Correspondence: clzhang2008@yahoo.cn; xgfan@hotmail.com

+ Contributed equally

${ }^{1}$ Department of Infectious Diseases, Xiangya Hospital, Central South University, Changsha, Hunan, PR China

${ }^{6}$ School of Public Health, Central South University, Changsha, Hunan, PR China

Full list of author information is available at the end of the article
}

and antiviral drugs including lamivudine(LAM), telbivudine(LdT), entecavir(ETV), adefovir(ADV), and tenofovir (TDF) [3].

Adefovir dipivoxil, an acylic phosphonate, is a nucleotide analog licensed for the treatment of HBV, which is active against both negative and positive $\mathrm{HBeAg}[4,5]$. Furthermore, it has been shown that ADV has an excellent activity against wild-type as well as LAM-resistant HBV strains [6,7]. However, ADV has low HBeAg seroconversion rate which was only $12 \%$, less potency toward HBV DNA suppression and a few drawbacks including nephrotocicity for those who are at risk for renal dysfunction [5]. Meanwhile at the licensed dose of $10 \mathrm{mg} /$ day ADV is not a highly potent drug [8]. But the advantage of ADV was the low rates of resistance. In contrast to LAM, after 2 and 4 years of ADV treatment only $3 \%, 18 \%$ of patients exhibit resistance respectively [9]. In addition, both the ADV mutations, N236T and
C Biomed Central

() 2011 Zhao et al; licensee BioMed Central Ltd. This is an Open Access article distributed under the terms of the Creative Commons Attribution License (http://creativecommons.org/licenses/by/2.0), which permits unrestricted use, distribution, and reproduction in any medium, provided the original work is properly cited. 
A181V, are susceptible to LAM. So ADV is a safe and effective treatment option for HBV infection.

Tenofovir disoproxil fumarate (TDF), a new nucleotide analogue licensed in 2008 for the treatment of HBV infections in Europe and the United States [10], also exhibits an efficacious activity against wild type and LAM-resistant HBV, both in vitro[11] and in vivo $[12,13]$. Randomized clinical trials have shown that TDF is more potent than ADV in inhibiting HBV replication in patients with chronic hepatitis [14]. The same study showed the efficacy of TDF in patients with a LAM-resistant virus and the absence of resistant mutations after 48 weeks of therapy. Besides, it has shown antiviral efficacy against a broad spectrum of viral infections, including human immunodeficiency virus (HIV-1)[15].

Treatment of CHB with TDF versus ADV have been reported in six independent studies [14,16-19], two of them $[16,18]$ on HIV-HBV coinfected patients and another two of them on patients with LAM-resistant $[17,19]$. These studies suggest a more promising result using TDF than ADV. However, there are important differences among these trials in study design, patient populations and patient status. The aims of this review are to summarize their findings and assess the impact on our management of the disease.

\section{Methods}

\subsection{Search strategy}

We searched the following databases until August 2010: PUBMED (from 1990 to August 2010), Web of Science (from 1990 to August 2010), EMBASE (from 1990 to August 2010), CNKI (National Knowledge Infrastructure) (from 1990 to August 2010), VIP database (from 1990 to August 2010), WANFANG database (from 1990 to August 2010), the Cochrane Central Register of Controlled Trials and the Cochrane Database of Systematic Review. Of these databases, CNKI, WANFANG and VIP databases provide literatures in Chinese. The search process was designed to find initially all trials involving terms: "Hepatitis B", "tenofovir", "adefovir"(and multiple synonyms for each term). Reference lists from retrieved documents were also searched. Computer searches were supplemented with a manual search. Search results were downloaded to a reference database and further screened. Two authors (Shushan Zhao and Lanhua Tang) independently screened all citations and abstracts identified by the search strategy to identify potentially eligible studies.

\subsection{Types of studies}

All relevant clinical trials will be included, irrespective of language, or blinding. Observational studies will be excluded except for their report on harms.

\subsection{Types of participants}

Male or female patients, of any age or ethnic origin, who have $\mathrm{CHB}$, defined as $\mathrm{CHB}$ virus infection with evidence of hepatitis (alanine aminotransferase (ALT) elevation of at least one and a half times the upper limit of normal range) and of viral replication (detectable hepatitis B virus DNA by DNA hybridisation method or polymerase chain reaction (PCR)), will be included. Patients with decompensated liver disease, hepatocellular carcinoma, prior liver transplantation and concomitant renal failure were excluded.

\subsection{Types of interventions}

The comparisons will include TDF versus ADV.

\subsection{Types of outcome measures}

Proportion of patients with HBV-DNA level under 1000 copies/ml, ALT normalization rate, HBeAg seroconversion rate, HBsAg loss rate.

\subsection{Data extraction}

Data was extracted independently by both authors (Shushan Zhao and Lanhua Tang) using a pre-designed data extraction form and the information subsequently was entered into Review Manager (RevMan 5.0). Information was extracted on data source; eligibility; methods; participants (age range, exclusion criteria, sample size, gender); interventions; and results. We resolved any discrepancies between the extracted data by discussion, and, if required, referral to the third author (Rongrong Zhou). Where data were not clear or not presented by the author in the publication, we attempted to contact the trial author for further details. Data was extracted on the methodological domains relevant to minimising bias and random error in the analysis of trials by using the Cochrane methods for assessing risk of bias and GRADE methods [20]. Specifically, we assessed study limitations by evaluating the method of randomisation, allocation concealment, blinding, analysis by intention to screen, free of selective reporting and so on. As perGRADE [20], we further assessed the quality of evidence with regard to limitations in designs, inconsistency, indirectness, imprecision, and other potential sources of bias, such as publication and reporting bias. GRADE criteria were then applied to downgrade the quality of evidence when indicated on an outcome specific basis. The quality of evidence for an individual outcome was ultimately rated as high, moderate, low, or very low.

\subsection{Quality assessment}

Quality of the trials was assessed using the QUOROM guidelines as well as using the Jadad scale. These prompted downgrading of the overall quality of evidence for all individual outcomes. 


\subsection{Data analysis}

Data analysis was carried out with the use of Review Manager Software 5.0(Cochrane Collaboration, Oxford, United Kingdom). For each eligible study, dichotomous data were presented as relative risk (RR), which is the probability that a member of an exposed group will develop a disease relative to the probability that a member of an unexposed group will develop that same disease, and continuous outcomes were presented as weighted mean difference (WMD), which is calculated as the difference between the mean value in the treatment and control groups, both with $95 \%$ confidence intervals (CI). Meta-analysis was performed using fixed-effect or random-effect methods, depending on the absence or presence of significant heterogeneity. Statistical heterogeneity between trials was evaluated by the chi-square and I-square $\left(\mathrm{I}^{2}\right)$ tests, with significance set at $\mathrm{P}<0.10$. In the absence of statistically significant heterogeneity, the fixed-effect method was used to combine the results. When heterogeneity was confirmed $(P<0.10)$, the random-effect method was used. Additionally, sensitivity analysis should be carried out if low quality trials were included. The overall effect was tested using z scores calculated by Fisher's z' transformation, with significance set at $\mathrm{P}<0.05$.

\section{Results}

We searched relevant literatures, and finally a total of 1425 studies identified by the searches(PUBMED:161; Web of Science:404; EMBASE:844; CNKI:3; VIP database:1; WANFANG database:1; the Cochrane Central Register of Controlled Trials and the Cochrane Database of Systematic Review:11). By scanning titles and abstracts, 722 redundant publications, review, and meta-analysis were excluded. After referring to full texts, 697 studies that did not satisfy the inclusion criteria were removed from consideration. Six studies [14,16-19] were left for analysis which involved 910 patients in total, of whom 576 were included in TDF groups and 334 were included in ADV groups (Figure $1)$. According to treatment period, we divided the studies into two subgroups: LAM-resistance group and HBV-HIV coinfected group. In addition, all studied populations with comparable baseline characteristics between TDF groups and ADV groups. Of the six trials, all were published in English. The detailed information of included trials was summarized in Table 1 and Table 2. With the exception of the study by van Bommel et al [19]., which was not referred, all were multicentred. However only four studies $[14,17,18]$ were multicentred involving sites in different countries. The lastest one [14] was a phase $\square$ trial comparing TDF with ADV. Of all trials, three were random double-blind trials. The treatment duration was more than 48 weeks and the end points were assessed at week 48 .
All six trials contained patients of similar demographics in terms of age and sex distribution(Table 1). The majority of patients were in their third or fourth decade of age and there was a male preponderance in all studies. Two studies $[17,19]$ included LAM-resistance patients and two studies $[16,18]$ included HIVHBV coinfetion patients. Different HBV-DNA assays were used in these studies and thus the HBV-DNA levels may not be directly comparable between studies.

In the trial by van Bommel et al [19], results showed that TDF coped more effectively with the LAM-resistant virus population than ADV at week 48 which were in accordance with results from previous studies demonstrating a HBV DNA decline at week 24. In this trial, TDF is superior to ADV considering the fact that in all TDF-treated patients HBV DNA became negative compared with only approximately $44 \%$ of the ADV group. And ALT levels normalized more rapidly in the TDF group than in the ADV group. Interestingly, 5 of the TDF-treated patients lost HBsAg. No major clinical side effects were reported during treatment with either TDF or ADV. In the trial by Hann et a[17] $l$, results showed that after 6 months treatment, HBV DNA levels were significantly reduced for the TDF group than for the ADV group. After 12 months on therapy, mean HBV DNA levels were reduced to $1.5 \pm 1.0 \log$ copies $/ \mathrm{ml}$ for the TDF group and $4.3 \pm 2.2 \log$ copies $/ \mathrm{ml}$ for the ADV group and the difference was significant which accorded with the result of Bommel's. However ALT normalization and HBeAg loss at 12 months showed no significant difference between two group.

In the study by Peters et al [18], either ADV or TDF treatment resulted in clinically significant reductions in serum HBV DNA levels in coinfected patients. TDF was not inferior to ADV according to the HBV DNA suppression. At week 48, 25\% of subjects on ADV and 36\% of subjects on TDF normalized serum ALT, but these numbers were not statistically significant either.

But in the study by Lacombe et al [16], the HBV-DNA decay was more significant in patients treated with TDF than with ADV, even after adjustment for baseline HBV viral load. And undetectability (HBV-DNA $<200$ copies $/ \mathrm{mL}$ ) was reached by $66 \%$ and $28 \%$ patients treated with TDF and ADV, respectively $(\mathrm{p}=0.04)$. However similar rates of $\mathrm{HBeAg}$ seroconversion and $\mathrm{HBsAg}$ loss were found between two groups.

The study by Marcellin et al [14] include two trials: study 102 (HBeAg-negative patients) and study 103 (HBeAg-positive patients). In both studies, a significantly greater proportion of patients who received TDF than patients who received ADV reached the HBV DNA level of less than 400 copies/ml. Among the HBeAg-negative patients, $93 \%$ of all the patients who received TDF had a plasma HBV DNA level of less than 400 copies/ml by 


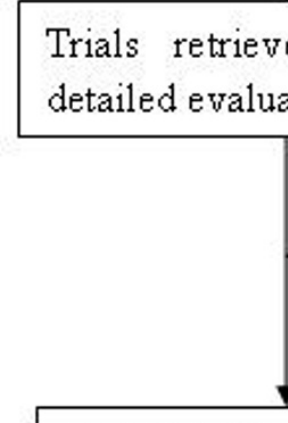

Potentially relevant trials identified and screened for retrieval $(\mathrm{n}=1425)$

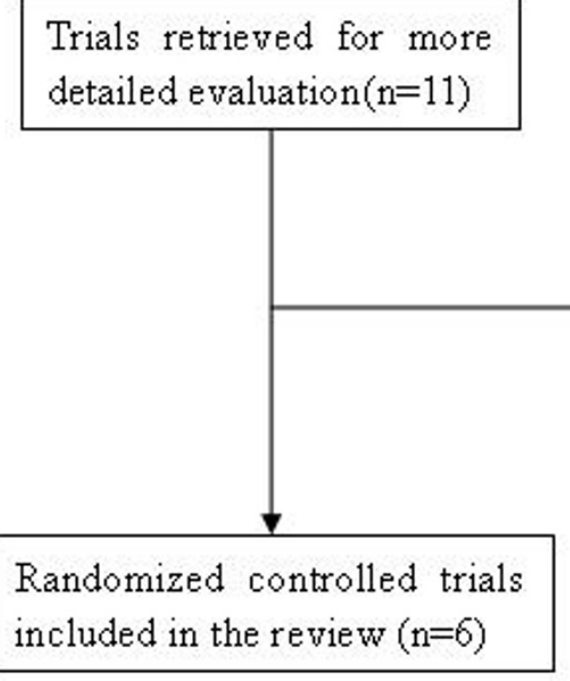

Not randomised controlled trials $(\mathrm{n}=692)$

Figure 1 Flow diagram of the studies identified.

week 48 while $63 \%$ of all the patients who received ADV $\operatorname{had}(\mathrm{p}<0.01)$. Among HBeAg-positive patients, $76 \%$ of patients who received TDF had an HBV DNA level of less than 400 copies $/ \mathrm{ml}$ at week 48 while 13 of patients who received ADV had(p < 0.01). In Study 102, similar proportions of patients in the two treatment groups had normalized alanine aminotransferase levels at week 48, whereas in Study 103, a significantly greater proportion of patients in the TDF group had normalized alanine aminotransferase levels.

Despite the differences in types of patient population, study design and patients' status, the six trials appear to demonstrate that TDF is superior to ADV in HBV-DNA decay. However there are different results on ALT normalization. So a meta-analysis is necessary to combine the results of those six studies.

Only three trials $[14,19]$ demonstrated the HBV-DNA level decreases below 400 copies/ml. According to chisquared statistic and I square $\left(\mathrm{I}^{2}\right)$, heterogeneity was assessed and had significant differences $\left[\mathrm{Tau}^{2}=0.65\right.$; $\mathrm{Chi}^{2}=35.89$, df $\left.=2(\mathrm{P}<0.00001) ; \mathrm{I}^{2}=94 \%\right]$. A summary estimate of the relative risk of TDF versus ADV by use of a random-effects approach. The results of the three trials showed HBV-DNA level below 400 copies/ $\mathrm{ml}$ in the TDF group was $87.2 \%$, compared to $42.5 \%$ in the ADV group at week 48. And the efficacy of HBVDNA suppression rates in TDF group was higher than ADV group $[R R=2.59,95 \% C I(1.01-6.67), P=0.05]$ 
Table 1 Summary of study design of the six trials

\begin{tabular}{|c|c|c|c|c|c|c|}
\hline Study & $\begin{array}{c}\text { Marcellin Study } 102 \\
{[14]}\end{array}$ & $\begin{array}{c}\text { Marcellin Study } 103 \\
{[14]}\end{array}$ & Lacombe [16] & Hann [17] & Peters [18] & van Bommel [19] \\
\hline $\begin{array}{l}\text { Study } \\
\text { location }\end{array}$ & Worldwide & Worldwide & French multi-centre & Asian-Americans & Worldwide & N/A \\
\hline $\begin{array}{l}\text { Study } \\
\text { design }\end{array}$ & $\begin{array}{l}\text { randomized,double- } \\
\text { blind }\end{array}$ & $\begin{array}{l}\text { randomized,double- } \\
\text { blind }\end{array}$ & $\begin{array}{l}\text { non-randomized, } \\
\text { open label }\end{array}$ & $\begin{array}{c}\text { quasi-randomized, } \\
\text { open-label }\end{array}$ & $\begin{array}{c}\text { prospective } \\
\text { randomized, double- } \\
\text { blind }\end{array}$ & $\begin{array}{l}\text { Nonrandmoized, } \\
\text { open-label }\end{array}$ \\
\hline Grade & 5 & 5 & 2 & 3 & 5 & 2 \\
\hline $\begin{array}{l}\text { Treatment } \\
\text { options }\end{array}$ & $\begin{array}{l}\text { Tenofovir } 300 \mathrm{mg} / \mathrm{d} \\
\text { vs Adefovir } 10 \mathrm{mg} / \mathrm{d}\end{array}$ & $\begin{array}{l}\text { Tenofovir } 300 \mathrm{mg} / \mathrm{d} \\
\text { vs Adefovir } 10 \mathrm{mg} / \mathrm{d}\end{array}$ & $\begin{array}{l}\text { Tenofovir } 300 \mathrm{mg} / \mathrm{d} \\
\text { vs Adefovir } 10 \mathrm{mg} / \mathrm{d}\end{array}$ & $\begin{array}{l}\text { Tenofovir } 300 \mathrm{mg} / \mathrm{d} \\
\text { vs Adefovir } 10 \mathrm{mg} / \mathrm{d}\end{array}$ & $\begin{array}{l}\text { Tenofovir } 300 \mathrm{mg} / \mathrm{d} \\
\text { vs Adefovir } 10 \mathrm{mg} / \mathrm{d}\end{array}$ & $\begin{array}{l}\text { Tenofovir } 300 \mathrm{mg} / \mathrm{d} \\
\text { vs Adefovir } 10 \mathrm{mg} / \mathrm{c}\end{array}$ \\
\hline Male & 193(77\%) vs. 97(78\%) & $119(68 \%)$ vs. $64(71 \%)$ & $\begin{array}{c}\text { 54(96.4\%) vs. } 28 \\
(26.6 \%)\end{array}$ & $37(85 \%)$ vs. $49(76 \%)$ & $\begin{array}{c}24 \text { (89\%) vs. } 24 \\
(96 \%)\end{array}$ & $\begin{array}{c}\text { 32(91.4\%) vs. } 14 \\
(77.8 \%)\end{array}$ \\
\hline $\begin{array}{c}\text { Mean age, } \\
\text { years }\end{array}$ & $\begin{array}{l}44 \pm 10.6 \text { vs } \\
43 \pm 10\end{array}$ & $34 \pm 11$ vs. $34 \pm 12$ & 42.3 vs. 41.5 & 49 vs. 45 & 40 vs. 47 & $47 \pm 2$ vs. $45 \pm 3.7$ \\
\hline $\begin{array}{l}\text { HBeAg- } \\
\text { positive } \\
\text { (\%) }\end{array}$ & $0: 0$ & $1: 1$ & $\begin{array}{c}50(89.3 \%) \text { vs. } 25 \\
(86.2 \%)\end{array}$ & $33(75 \%)$ vs. $55(84 \%)$ & $\begin{array}{c}23 \text { (85\%) vs. } 20 \\
\text { (80\%) }\end{array}$ & $31(89 \%)$ vs16( $89 \%)$ \\
\hline $\begin{array}{l}\text { Treatment } \\
\text { (weeks) }\end{array}$ & 48 weeks & 48 weeks & 48 weeks & 48 weeks & 48 weeks & $\begin{array}{c}72 \text { to } 130 \text { weeks vs. } \\
60 \text { to } 80 \text { weeks }\end{array}$ \\
\hline $\begin{array}{l}\text { Follow-up } \\
\text { (weeks) }\end{array}$ & N/A & N/A & N/A & 48 weeks & $\begin{array}{c}91 \text { weeks vs. } 81 \\
\text { weeks }\end{array}$ & N/A \\
\hline Status & N/A & N/A & Coinfect HIV & lamivudine-resistant & Coinfect HIV & lamivudine-resistant \\
\hline
\end{tabular}

(Figure 2). However, the conclusion was changed when the low quality trial [19] was removed[RR $=2.58,95 \%$ $\mathrm{CI}(0.56-14.56), \mathrm{P}=0.21]$. The quality of evidence for this effect was judged low (Table 3). Just one study [19] demonstrated the HBV-DNA level decreases below 400 copies/ml in LAM-resistance subgroup. The result showed the HBV-DNA suppression rates in TDF group was higher than ADV group $[R R=2.20$, 95\% CI $(1.34$ $3.64), P=0.002]$. Two studies $[16,18]$ demonstrated the HBV-DNA level decreased below 200 copies $/ \mathrm{ml}$ in HBV-HIV coinfected subgroup. The results showed HBV-DNA level below 200 copies/ml for in the TDF group was $50.6 \%$, compared to $18.5 \%$ in the ADV group at week 48. And the HBV-DNA suppression rates in TDF group was higher than ADV group $[R R=2.38,95 \%$ $\mathrm{CI}(1.34-4.24), \mathrm{P}=0.003]$ (Figure 3 ). The quality of evidence for this effect was judged moderate.

Five studies [14,17-19] demonstrated the ALT normalization rate in this subgroup. According to chi-squared statistic and I square $\left(\mathrm{I}^{2}\right)$, a random-effects approach was used to summary estimate the relative risk of TDF versus ADV. The results of the five trials showed normalization rates for ALT in the TDF group as $72.1 \%$, compared to $63.3 \%$ in the ADV group at week 48. And the biochemical response rates in TDF group was similar with the ADV group $[\mathrm{RR}=1.15,95 \% \mathrm{CI}(0.96-1.37), \mathrm{P}=0.14]$ (Figure 4). The quality of evidence for this effect was judged low. The result was unchanged when low quality trials $[17,19]$ were removed $[\mathrm{RR}=1.08,95 \% \mathrm{CI}(0.87-1.33), \mathrm{P}=$ 0.49]. The quality of evidence for this effect was judged moderate. In the LAM-resistance subgroup, a fix-effects approach was used to summary estimate the relative risk of TDF versus ADV and the efficacy of TDF versus ADV on ALT normalization rates is also similar $[R R=1.32$, $95 \% \mathrm{CI}(1.00-1.74), \mathrm{P}=0.05$ ] (Figure 5$)$. The quality of evidence for this effect was judged low.

Three trials $[14,16,17]$ demonstrated the HBeAg seroconversion rate in this subgroup. According to chisquared statistic and I square $\left(\mathrm{I}^{2}\right)$, heterogeneity was assessed and not found to be a concern $\left[\mathrm{Chi}^{2}=0.00, \mathrm{df}=1\right.$

Table 2 Methodological quality of randomised controlled trials

\begin{tabular}{|c|c|c|c|c|c|c|}
\hline Study & $\begin{array}{l}\text { Adequate sequence } \\
\text { generation }\end{array}$ & $\begin{array}{c}\text { Allocation } \\
\text { concealment }\end{array}$ & Blinding & $\begin{array}{l}\text { Incomplete outcome data } \\
\text { addressed }\end{array}$ & $\begin{array}{l}\text { Free of selective } \\
\text { reporting }\end{array}$ & $\begin{array}{l}\text { Free of other } \\
\text { bias }\end{array}$ \\
\hline $\begin{array}{l}\text { Marcellin Study } \\
102[14]\end{array}$ & yes & yes & yes & yes & yes & yes \\
\hline $\begin{array}{l}\text { Marcellin Study } \\
103[14]\end{array}$ & yes & yes & yes & yes & yes & yes \\
\hline Lacombe [16] & no & no & no & yes & yes & unclear \\
\hline Hann [17] & unclear & unclear & unclear & yes & unclear & unclear \\
\hline Peters [18] & yes & yes & yes & yes & yes & yes \\
\hline van Bommel [19] & no & no & no & yes & yes & unclear \\
\hline
\end{tabular}




\begin{tabular}{|c|c|c|c|c|c|c|c|c|}
\hline Study or Subgroup & \multicolumn{2}{|c|}{ Tenofovir } & \multicolumn{2}{|c|}{ Adefovir } & Weight & $\begin{array}{c}\text { Risk Ratio } \\
\text { M-H, Random, } 95 \% \mathrm{Cl}\end{array}$ & \multicolumn{2}{|c|}{$\begin{array}{c}\text { Risk Ratio } \\
\text { M-H, Random, } 95 \% \mathrm{Cl}\end{array}$} \\
\hline Marcellin study 1032008 & 134 & 176 & 12 & 90 & $32.1 \%$ & $5.71[3.35,9.73]$ & & - \\
\hline Marcellin-study 1022008 & 233 & 250 & 79 & 125 & $35.5 \%$ & $1.47[1.28,1.69]$ & & ${ }^{2}$ \\
\hline van Bommel 2004 & 35 & 35 & 8 & 18 & $32.5 \%$ & $2.20[1.34,3.64]$ & & \\
\hline Total $(95 \% \mathrm{Cl})$ & & 461 & & 233 & $100.0 \%$ & $2.59[1.01,6.67]$ & & \\
\hline Total events & 402 & & 99 & & & & & \\
\hline $\begin{array}{l}\text { Heterogeneity: } \mathrm{Tau}^{2}=0.6 \\
\text { Test for overall effect: } Z=\end{array}$ & $\begin{array}{l}\mathrm{Chi}^{2}=35 \\
98(P=0 .\end{array}$ & $\begin{array}{l}89, \mathrm{df} \\
.05)\end{array}$ & $=2(P<0$ & 0.0001 & 1); $\left.\right|^{2}=94 \%$ & & $\begin{array}{l}0.10 .2 \\
\text { Favours adefovir }\end{array}$ & $\begin{array}{|ccc|} & 5 & 10 \\
\text { Favours tenofovir }\end{array}$ \\
\hline
\end{tabular}

$\left.(\mathrm{P}=0.97) ; \mathrm{I}^{2}=0 \%\right]$. The results of the three studies showed the HBeAg seroconversion rate for the TDF group was $18.6 \%$ while the ADV group response rate was $14.0 \%$. The difference of HBeAg seroconversion rates at week 48 between the two group was similar $[\mathrm{RR}=1.19,95 \% \mathrm{CI}$ (0.74-1.91), $\mathrm{P}=0.48$ ] (Figure 6). The quality of evidence for this effect was judged low. Two trials demonstrated the HBsAg loss rate in this subgroup and the difference of HBsAg loss rate between the two group was similar $[\mathrm{RR}=$ $5.74,95 \% \mathrm{CI}(0.32-102.59), \mathrm{P}=0.23]$. The quality of evidence for this effect was judged high (Table 3 ).

\section{Toleraility and safety of tenofovir and adefovir}

The most frequently reported adverse events in TDFtreatmented patients, which included headache, nasopharyngitis, fatigue, diarrhea, upper abdominal pain, and so on, were those normally associated with ADV except nausea. In Marcellin's trial, it's report that nausea was the only adverse event that consistently occurred more frequently in the group of patients who received TDF than in the group of patients who received ADV. Among the cases of nausea that were considered to be related to TDF, nausea was mild except for one case of grade 2 (moderate) nausea. Despite presence of these adverse effects, rate of withdrawal from both treatments was rare in all studies. In both studies, similar proportions of patients in the two treatment groups had a serious adverse event, and few events were considered to be related to the study drug. The frequency of alanine aminotransferase flares during treatment was also similar in the two groups. These was no death associated with the treatment, or liver decompensation.

\section{Dicussion}

There have been several meta-analysis comparing drugs in the treatment of chronic hepatitis $B$ [21,22], but no comparison of the efficacy of TDF and ADV have been performed. So we conducted this meta-analysis to compare antiviral efficacy of TDF and ADV in the treatment of $\mathrm{CHB}$; despite variations in study design among the

Table 3 Methodological quality of randomised controlled trials

\begin{tabular}{|c|c|c|c|c|c|}
\hline \multirow[t]{3}{*}{ Outcomes } & \multicolumn{2}{|c|}{ Illustrative comparative risks* $(95 \% \mathrm{CI})$} & \multirow{3}{*}{$\begin{array}{l}\text { Relative effect } \\
(95 \% \mathrm{CI})\end{array}$} & \multirow{3}{*}{$\begin{array}{c}\text { No of Participants } \\
\text { (studies) }\end{array}$} & \multirow{3}{*}{$\begin{array}{l}\text { Quality of the evidence } \\
\text { (GRADE) } \dagger\end{array}$} \\
\hline & $\begin{array}{l}\text { Assumed risk (per } \\
1000)\end{array}$ & $\begin{array}{l}\text { Corresponding risk } \\
\text { (per 1000) }\end{array}$ & & & \\
\hline & Adefovir & Tenofovir & & & \\
\hline HBV-DNA suppression & 425 & $1000(429$ to 1000$)$ & $\begin{array}{c}\text { RR } 2.59(1.01 \text { to } \\
6.67)\end{array}$ & 694(3 studies) & low $\oplus \oplus 0 \mathrm{Q}$ \\
\hline $\begin{array}{l}\text { HBV-HIV coinfected } \\
\text { subgroup }\end{array}$ & 185 & $440(248$ to 784$)$ & $\begin{array}{c}\text { RR } 2.38 \text { (1.34 to } \\
4.24)\end{array}$ & 137(2 studies) & moderate $\oplus \oplus \oplus \square$ \\
\hline ALT normalization & 634 & $729(609$ to 869$)$ & $\begin{array}{c}\text { RR } 1.15 \text { (0.96 to } \\
1.37)\end{array}$ & 768(5 studies) & low $\oplus \oplus \varphi^{\circ}$ \\
\hline $\begin{array}{l}\text { lamivudine-resistance } \\
\text { subgroup }\end{array}$ & 554 & $731(554$ to 964$)$ & $\begin{array}{c}\text { RR } 1.32(1.00 \text { to } \\
1.74)\end{array}$ & 132(2 studies) & low $\oplus \oplus$ lo \\
\hline HBeAg seroconversion & 140 & $167(104$ to 267$)$ & $\begin{array}{c}\text { RR } 1.19(0.74 \text { to } \\
1.91)\end{array}$ & 387(3 studies) & low $\oplus \oplus \square \square$ \\
\hline HBsAg loss & 0 & 0 & $\begin{array}{c}\text { RR } 5.74(0.32 \text { to } \\
102.59)\end{array}$ & 615 (2 studies) & high $\oplus \oplus \oplus \oplus$ \\
\hline
\end{tabular}

*The corresponding risk (and its $95 \% \mathrm{Cl}$ ) is based on the assumed risk in the entecavir group and the relative effect of the lamivudine (and its $95 \% \mathrm{Cl}$ ). tHigh quality: Further research is very unlikely to change our confidence in the estimate of effect.

Moderate quality: Further research is likely to have an important impact on our confidence in the estimate of effect and may change the estimate. Low quality: Further research is very likely to have an important impact on our confidence in the estimate of effect and is likely to change the estimate. Very low quality: We are very uncertain about the estimate. 


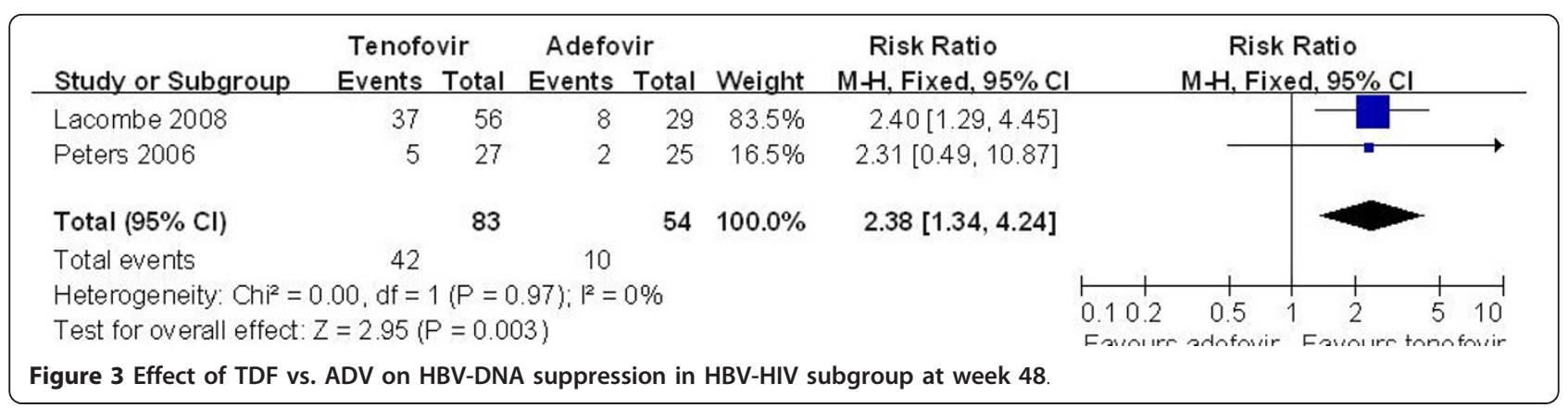

six studies, the results were nearly similar, which showed that at the end of 12 months treatment, TDF was better than ADV at the HBV-DNA suppression, while there was no significant difference in the ALT normalization, $\mathrm{HBeAg}$ seroconversion and HBsAg loss rate. Meanwhile there are similar results in the ALT normalization in the LAM-resistance and suppression of viral replication in HIV-HBV coinfected subgroup. The inter-heterogeneity was not statistically significant(P > 0.1 ). There were on changes about effect when a random-effect model was used. Interestingly, the result of HBV-DNA suppression was changed when the low quality [19] trial was removed $[\mathrm{RR}=2.58,95 \% \mathrm{CI}(0.56-14.56)$ $\mathrm{P}=0.21]$. But the confidence intervals became wider, so we think that the findings should be reinterpreted when more researches done. Adverse events related to TDF and ADV did occur but none appeared to be lifethreatening. So this meta-analysis showed that TDF was a more potent therapy for the treatment of chronic HBV infection than ADV. However, TDF was just effective in suppressing HBV-DNA levels. Considering its favorable long-term safety record in patients with HIV-1 infection, TDF should be used for the treatment of chronic HBV infection.

While the results of this meta-analysis were promising, there are questions that remain unresolved. Peters and Lacombe's study $[16,18]$ have been the only two trials to compare efficacy of HBV-DNA suppression in HIV coinfected patients, however those two trials have a small sample size and different study location. van Bommel and Hann's trials $[17,19]$ have been the only two studies to compare efficacy of ALT normalization in LAM-resistance patients, however both trials have a low Jadad score and small sample size. Although this metaanalysis showed TDF was superior to ADV on HBV DNA suppression in HIV-coinfected subgroup, these two trials had different Jadad score. And when the low quality [16] trials was removed, the conclusion was changed [RR $=2.31,95 \% \mathrm{CI}(0.49-10.87), \mathrm{P}=0.29]$. So is TDF really more efficacious than ADV on HBV-DNA suppression in the HIV coinfected patients and similar with ADV on ALT normalization in the LAM-resistance subgroup? More solid data is needed in the future. Another unresolved issue is related to the $\mathrm{HBeAg}$ seroconversion and HBsAg loss to TDF and ADV therapy in HBV infection. The studies so far have provided no evidence of efficacy in terms of HBeAg seroconversion and HBsAg loss. Meanwhile, follow-up of patients will be needed to detect delayed viral suppression or relapse. More importantly, the clinical outcomes in terms of liver-related complications, mortality and hepatocellular carcinoma should be assessed [23]. Besides there are different outcomes on HBV-DNA level in the six trials and it made difficult to extract data, so it is necessary to make a basic uniform standards for all trails outcome. After all, more high-quality, well-designed, randomized controlled,

\begin{tabular}{|c|c|c|c|c|c|c|c|}
\hline Study or Subgroup & $\begin{array}{l}\text { Tenofo } \\
\text { Events }\end{array}$ & $\begin{array}{l}\text { vir } \\
\text { Total }\end{array}$ & $\begin{array}{r}\text { Ad efo } \\
\text { Events }\end{array}$ & $\begin{array}{l}\text { vir } \\
\text { Total }\end{array}$ & Weight & $\begin{array}{c}\text { Risk Ratio } \\
\text { M-H, Random, } 95 \% \mathrm{Cl}\end{array}$ & $\begin{array}{c}\text { Risk Ratio } \\
\mathrm{M}-\mathrm{H}, \text { Random, } 95 \% \mathrm{Cl}\end{array}$ \\
\hline Hann 2008 & 21 & 32 & 26 & 47 & $16.6 \%$ & $1.19[0.83,1.70]$ & +- \\
\hline Marcellin study 1032008 & 180 & 236 & 91 & 118 & $40.0 \%$ & $0.99[0.88,1.12]$ & \\
\hline Marcellin-study 1022008 & 115 & 169 & 49 & 90 & $28.7 \%$ & $1.25[1.01,1.55]$ & $=$ \\
\hline Peters 2006 & 3 & 12 & 4 & 11 & $2.0 \%$ & $0.69[0.20,2.41]$ & \\
\hline van Bommel 2004 & 30 & 35 & 10 & 18 & $12.7 \%$ & $1.54[1.00,2.38]$ & \\
\hline Total $(95 \% \mathrm{Cl})$ & & 484 & & 284 & $100.0 \%$ & $1.15[0.96,1.37]$ & 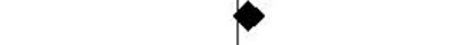 \\
\hline \multirow{2}{*}{\multicolumn{6}{|c|}{$\begin{array}{l}\text { Heterogeneity: } \text { Tau }^{2}=0.02 ; \mathrm{Chi}^{2}=7.52, \mathrm{df}=4(\mathrm{P}=0.11) ; \mathrm{I}^{2}=47 \% \\
\text { Test for overall effect: } Z=1.48(P=0.14)\end{array}$}} & & \\
\hline & & & & & & & 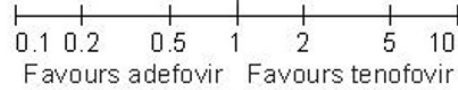 \\
\hline
\end{tabular}




\begin{tabular}{|c|c|c|c|c|c|c|c|}
\hline Study or Subgroup & $\begin{array}{l}\text { Tenofo } \\
\text { Events }\end{array}$ & $\begin{array}{l}\text { vir } \\
\text { Total }\end{array}$ & $\begin{array}{l}\text { Adefor } \\
\text { Events }\end{array}$ & $\begin{array}{l}\text { vir } \\
\text { Total }\end{array}$ & Weight & $\begin{array}{l}\text { Risk Ratio } \\
\text { M-H, Fixed, } 95 \% \mathrm{Cl}\end{array}$ & $\begin{array}{l}\text { Risk Ratio } \\
\mathrm{M}+\mathrm{H}, \text { Fixed, } 95 \% \mathrm{Cl}\end{array}$ \\
\hline Hann 2008 & 21 & 32 & 26 & 47 & $61.5 \%$ & $1.19[0.83,1.70]$ & \\
\hline van Bommel 2004 & 30 & 35 & 10 & 18 & $38.5 \%$ & $1.54[1.00,2.38]$ & \\
\hline Total $(95 \% \mathrm{Cl})$ & & 67 & & 65 & $100.0 \%$ & $1.32[1.00,1.75]$ & \\
\hline Total events & 51 & & 36 & & & & \\
\hline \multicolumn{7}{|c|}{$\begin{array}{l}\text { Heterogeneity: } C h i^{2}=0.83, \mathrm{df}=1(P=0.36) ;\left.\right|^{2}=0 \% \\
\text { Test for overall effect: } Z=1.99(P=0.05)\end{array}$} & \begin{tabular}{|cccccc} 
& 1 & 1 & 1 & $\mid$ & \\
0.10 .2 & 0.5 & 1 & 2 & 5 & 10 \\
Favours adefovir & Favours tenofovir
\end{tabular} \\
\hline
\end{tabular}

multi-center trails comparing TDF and ADV in LAMresistance or HIV coinfected patients would be needed.

There are several methodological limitations in the trials that have been reviewed warrant some discussion. First, only three studies were double-blinded. Although the intervention is easy to blind, there are several trials didn't use. However, it is unlikely that the lack of blinding could affect the outcomes assessed [24]. Second, as LAM-resistance and HIV-HBV coinfected patients were studied in two of the six included trials respectively, it is likely that our meta-analysis included different patient groups. So the multiple subgroup analyses are performed to detect the efficacy of TDF and ADV in the treatment of CHB. Third, three trials didn't describe the method used to generate the allocation sequence. Despite these potential sources of bias, randomization was adequate in the six trials as shown by the baseline equivalency of treatment groups. Finally, the different HBV DNA assays used in the different trials may also have caused additional variability in the sensitivity of HBV DNA detection and thus in the estimate of efficacy.

Another potentially important limitation of metaanalysis is publication bias, the fact that not all research is published. Compared to positive studies, negative studies may be less likely to be published and more likely to take longer to be published, which can affect the validity of meta-analysis [25]. One commonly used method to detect publication bias is the 'funnel plot,' which is a scatter plot that displays the relationship between the weight of the study and the observed effect. In principle, larger studies should display less variability of the treatment effects. Asymmetric appearance, especially due to the absence of smaller negative studies, can suggest unpublished data. However, neither Egger's test nor funnel plots showed evidence for publication bias.

In summary, the results of this meta-analysis indicate that a twelve-month TDF treatment was superior to ADV in inhibiting HBV replication in CHB patients. But there was no significant difference in the ALT normalization, $\mathrm{HBeAg}$ seroconversion and HBsAg loss rate. More high-quality, well-designed, randomized controlled, multi-center trails that are adequately powered are clearly needed to guide evolving standards of care for $\mathrm{CHB}$.

\section{Acknowledgements}

This work was financial supported by the Innovative Experimental Program for Undergraduates (YA09057).

\section{Author details}

${ }^{1}$ Department of Infectious Diseases, Xiangya Hospital, Central South University, Changsha, Hunan, PR China. ${ }^{2}$ Eight-Year Program, Xiangya School of Medicine, Central South University, Changsha, Hunan, PR China. ${ }^{3}$ Department of Spine Surgery, Xiangya Hospital, Central South University, Changsha, Hunan, PR China. ${ }^{4}$ Department of Neurology, Xiangya Hospital, Central South University, Changsha, Hunan, PR China. ${ }^{5}$ Department of Gastroenterology, Third Xiangya Hospital, Central South University, Changsha, Hunan, PR China. '5chool of Public Health, Central South University, Changsha, Hunan, PR China.

\begin{tabular}{|c|c|c|c|c|c|c|c|}
\hline Study or Subgroup & $\begin{array}{l}\text { Tenofo } \\
\text { Events }\end{array}$ & $\begin{array}{l}\text { vir } \\
\text { Total }\end{array}$ & $\begin{array}{l}\text { Adefor } \\
\text { Events }\end{array}$ & $\begin{array}{l}\text { vir } \\
\text { Total }\end{array}$ & Weight & $\begin{array}{c}\text { Risk Ratio } \\
\mathrm{M}-\mathrm{H} \text {, Fixed, } 95 \% \mathrm{Cl}\end{array}$ & $\begin{array}{c}\text { Risk Ratio } \\
\text { M-H, Fixed, } 95 \% \mathrm{Cl}\end{array}$ \\
\hline Hann 2008 & 4 & 37 & 3 & 49 & $9.7 \%$ & $1.77[0.42,7.41]$ & 710 \\
\hline Lacombe 2008 & 8 & 47 & 4 & 21 & $20.9 \%$ & $0.89[0.30,2.64]$ & \\
\hline Marcellin study 1032008 & 32 & 153 & 14 & 80 & $69.4 \%$ & $1.20[0.68,2.11]$ & \\
\hline Total $(95 \% \mathrm{Cl})$ & & 237 & & 150 & $100.0 \%$ & $1.19[0.74,1.91]$ & \\
\hline Total events & 44 & & 21 & & & & \\
\hline \multicolumn{7}{|c|}{$\begin{array}{l}\text { Heterogeneity: } \text { Chi }^{2}=0.56, \mathrm{df}=2(P=0.76) ;\left.\right|^{2}=0 \% \\
\text { Test for overall effect: } Z=0.71(P=0.48)\end{array}$} & $\begin{array}{cccc}0.01 & 0.1 & 1 & 10 \\
\text { Favours adefovir } & \text { Favours tenofovir }\end{array}$ \\
\hline
\end{tabular}




\section{Authors' contributions}

XGF conceived the study, provided fund supporting and revised the manuscript critically for important intellectual content. SSZ, RRZ and LHT made substantial contributions to its design, acquisition, analysis and interpretation of data. LZC, WW and XHD participated in the design, acquisition, analysis and interpretation of data. All authors contributed equally to this manuscript. All authors read and approved the final manuscript.

\section{Competing interests}

The funding source had no influence on study design, in the collection, analysis, and interpretation of the data, in the writing of the manuscript, or in the decision to submit the manuscript for publication. The contents are solely the responsibility of the authors and do not necessarily represent the views of the funding source.

Received: 19 November 2010 Accepted: 9 March 2011

Published: 9 March 2011

\section{References}

1. Safioleas M, Lygidakis NJ, Manti C: Hepatitis B today. Hepatogastroenterology 2007, 54:545-548.

2. Poland GA, Jacobson RM: Clinical practice: prevention of hepatitis $B$ with the hepatitis B vaccine. N Engl J Med 2004, 351:2832-2838.

3. Nash K: Telbivudine in the treatment of chronic hepatitis B. Adv Ther 2009, 26:155-169.

4. Hadziyannis SJ, Tassopoulos NC, Heathcote EJ, Chang TT, Kitis G, Rizzetto M, Marcellin P, Lim SG, Goodman Z, Wulfsohn MS, et al: Adefovir dipivoxil for the treatment of hepatitis B e antigen-negative chronic hepatitis B. N Engl J Med 2003, 348:800-807.

5. Marcellin P, Chang TT, Lim SG, Tong MJ, Sievert W, Shiffman ML, Jeffers L, Goodman Z, Wulfsohn MS, Xiong S, et al: Adefovir dipivoxil for the treatment of hepatitis B e antigen-positive chronic hepatitis B. N Engl J Med 2003, 348:808-816.

6. Chen EQ, Wang $L C$, Lei J, Xu L, Tang H: Meta-analysis: adefovir dipivoxil in combination with lamivudine in patients with lamivudine-resistant hepatitis B virus. Virol J 2009, 6:163.

7. Jiang $L$, Yan $L N$ : Current therapeutic strategies for recurrent hepatitis $B$ virus infection after liver transplantation. World I Gastroenterol 2010, 16:2468-2475.

8. Sherman M: Personal view: the management of chronic hepatitis B infection. Aliment Pharmacol Ther 2006, 23:857-869.

9. Delaney WEt: Progress in the treatment of chronic hepatitis B: long-term experience with adefovir dipivoxil. J Antimicrob Chemother 2007, 59:827-832.

10. Schooley RT, Ruane P, Myers RA, Beall G, Lampiris H, Berger D, Chen SS, Miller MD, Isaacson E, Cheng AK: Tenofovir DF in antiretroviralexperienced patients: results from a 48-week, randomized, double-blind study. AIDS 2002, 16:1257-1263.

11. Lada O, Benhamou Y, Cahour A, Katlama C, Poynard T, Thibault V: In vitro susceptibility of lamivudine-resistant hepatitis B virus to adefovir and tenofovir. Antivir Ther 2004, 9:353-363.

12. Benhamou $Y$, Tubiana $R$, Thibault $\mathrm{V}$ : Tenofovir disoproxil fumarate in patients with HIV and lamivudine-resistant hepatitis B virus. New England Journal of Medicine 2003, 348:177-178

13. Lacombe K, Gozlan J, Boelle PY, Serfaty L, Zoulim F, Valleron AJ, Girard PM: Long-term hepatitis B virus dynamics in HIV-hepatitis B virus-co-infected patients treated with tenofovir disoproxil fumarate. AIDS 2005, 19:907-915.

14. Marcellin P, Heathcote EJ, Buti M, Gane E, de Man RA, Krastev Z, Germanidis G, Lee SS, Flisiak R, Kaita K, et al: Tenofovir disoproxil fumarate versus adefovir dipivoxil for chronic hepatitis B. N Engl J Med 2008, 359:2442-2455.

15. van Bommel F, de Man RA, Wedemeyer H, Deterding K, Petersen J, Buggisch P, Erhardt A, Huppe D, Stein K, Trojan J, et al: Long-term efficacy of tenofovir monotherapy for hepatitis B virus-monoinfected patients after failure of nucleoside/nucleotide analogues. Hepatology 2010, 51:73-80.

16. Lacombe K, Gozlan J, Boyd A, Boelle PY, Bonnard P, Molina JM, Miailhes P, Lascoux-Combe C, Serfaty L, Zoulim F, Girard PM: Comparison of the antiviral activity of adefovir and tenofovir on hepatitis B virus in HIVHBV-coinfected patients. Antivir Ther 2008, 13:705-713.
17. Hann HW, Chae HB, Dunn SR: Tenofovir (TDF) has stronger antiviral effect than adefovir (ADV) against lamivudine (LAM)-resistant hepatitis B virus (HBV). Hepatol Int 2008, 2:244-249.

18. Peters MG, Andersen J, Lynch P, Liu T, Alston-Smith B, Brosgart CL, Jacobson JM, Johnson VA, Poflard RB, Rooney JF, et al: Randomized controlled study of tenofovir and adefovir in chronic hepatitis $B$ virus and HIV infection: ACTG A5127. Hepatology 2006, 44:1110-1116.

19. van Bommel F, Wunsche T, Mauss S, Reinke P, Bergk A, Schurmann D, Wiedenmann B, Berg T: Comparison of adefovir and tenofovir in the treatment of lamivudine-resistant hepatitis B virus infection. Hepatology 2004, 40:1421-1425.

20. Jadad AR, Moore RA, Carroll D, Jenkinson C, Reynolds DJ, Gavaghan DJ, McQuay HJ: Assessing the quality of reports of randomized clinical trials: is blinding necessary? Control Clin Trials 1996, 17:1-12.

21. Zhao $S$, Tang $L$, Fan $X$, Chen $L$, Zhou R, Dai X: Comparison of the efficacy of lamivudine and telbivudine in the treatment of chronic hepatitis B: a systematic review. Virol J 2010, 7:211.

22. Yang YF, Zhao $W$, Zhong YD, Yang YJ, Shen $L$, Zhang $N$, Huang $P$ : Comparison of the efficacy of thymosin alpha- 1 and interferon alpha in the treatment of chronic hepatitis B: a meta-analysis. Antiviral Res 2008, 77:136-141.

23. Hui AY, Chan HL, Cheung AY, Cooksley G, Sung JJ: Systematic review: treatment of chronic hepatitis B virus infection by pegylated interferon. Aliment Pharmacol Ther 2005, 22:519-528.

24. Juni P, Altman DG, Egger M: Systematic reviews in health care: Assessing the quality of controlled clinical trials. BMJ 2001, 323:42-46.

25. Thornton A, Lee P: Publication bias in meta-analysis: its causes and consequences. J Clin Epidemiol 2000, 53:207-216.

doi:10.1186/1743-422X-8-111

Cite this article as: Zhao et al:: Comparison of the efficacy of tenofovir and adefovir in the treatment of chronic hepatitis B: A Systematic Review. Virology Journal 2011 8:111.

\section{Submit your next manuscript to BioMed Central and take full advantage of:}

- Convenient online submission

- Thorough peer review

- No space constraints or color figure charges

- Immediate publication on acceptance

- Inclusion in PubMed, CAS, Scopus and Google Scholar

- Research which is freely available for redistribution
C BioMed Central 